\title{
Why is Immunohistochemical Detection of Metastasized Breast Cancer Cells in the Immunocompetent Host Not Always Easy?
}

\author{
Priyank A. Shenoy*
}

Faculty of Pharmacy and Pharmaceutical Sciences, Monash University, Melbourne, Victoria, Australia

\begin{abstract}
Metastases of breast cancer cells from the tissue of origin to distant sites including vital organs commonly occurs in patients suffering from breast cancer. Such metastases are detrimental to the quality of life of these patients. Clinical pathologists and basic researchers in the field of oncology commonly use techniques like immunohistochemistry to detect disseminated cancer cells in metastasized regions in an attempt to improve patient outcomes. This review sheds light on genotypic and phenotypic changes in disseminated cancer cells that occur during the ongoing process of metastasis, thereby leading to continuous changes in the expression levels of different markers expressed by these cells and making the immunohistochemical detection of breast cancer cells in the non-cognate tissues difficult.
\end{abstract}

Keywords: Breast cancer, metastasis, genotypic and phenotypic changes.

Immunohistochemical assessments are commonly used by pathologists to detect metastasized cancer cells in the regions distant from the tissue of origin of the cancer as these assessments are considered to be a more direct method of detection of the cells, compared to other methods $[1,2]$. However, the expression levels of such immunohistochemical markers in disseminated cancer cells can significantly vary from the cells in the tissue of origin. Heterogeneity of cancer cells is a very well-known phenomenon. In breast cancer, it may be difficult to clearly classify the cancer cells as marker-receptor- "positive" or "negative", as there can be significant intra-tumoral heterogeneity in their expression [3, 4]. Her2, Muc1 and cytokeratins are some of the classical breast cancer markers $[5,6]$. Intra-tumoral heterogeneity can typically be observed with such classical markers too, including Her2 [7-9], MUC1 [10] and cytokeratins [11, 12]. Such intra-tumoral heterogeneity in breast cancer occurs both at the genetic and morphological levels [13-17]. Due to the existence of mixed cell populations in the breast cancer tumours, they have the potential to differentially grow into diverse types like epithelial and fibroblastic, subject to different growth conditions [18].

One of the hallmark features of cancer cells is their genomic instability and this is what makes a cancer a cancer [19-21]. Cancer immunoediting comprises three Es- Elimination (immunosurveillance), Equilibrium and Escape; and the process leading from immunosurveillance to tumour escape in the immunocompetent host is well known [22]. As per the Darwinian selection theory, tumor-specific immune responses are

*Address correspondence to this author at the Faculty of Pharmacy and Pharmaceutical Sciences, Monash University, Melbourne, Victoria, Australia; E-mail: priyank.shenoy@monash.edu responsible for eliminating highly immunogenic tumor cells, while the tumor variants with reduced immunogenicity have a better chance of survival in the immunocompetent host [22-24]. Tumour cells have the ability to shed or restrict the presentation of ligands or antigens involved in their recognition by the host's immune system or down-regulate the expression of factors that promote activation of tumour-specific immune responses [25]. Due to the immune pressure, tumour cell variants with loss of such antigens emerge as a consequence of epigenetic mechanisms within the tumor [26, 27]. Likewise, the anti-tumor immune responses themselves can induce changes in antigenpositive cells, converting them into antigen-negative cells [28, 29]. Hence, discordance in receptor or biomarker status and genotypic heterogeneity between primary breast cancer cells and their metastasised lesions or circulating cells in the body is very common, because the biomarker expression of primary tumour cells can significantly change during the disease progression [30-39]. Similarly antigens that can be targeted by the immune system are also found to be lost in other types of human cancers [40-42]. Such immunoediting processes can be strong enough to induce very significant changes in morphology and microarray of the breast cancer cells, leading to failure in detection of earlier version of cells [43-50].

For example, Muc1 has several major limitations as a breast cancer marker and most cancer-expert panels around the world recommend against its use as a reliable marker even in the post-operative clinical setup in humans [5, 51]. Its expression is not always constant and changes massively based on the changes in endogenous biological processes [52]. MUC1 expression levels can change in cancer cell lines at the transcriptional level or even in vivo due to the effect of 
internal body hormones [53]. Muc1 is an epithelial marker [54], however, it is not necessarily expressed in all the cells within the tumour. For example, ovarian neoplasms constitute a heterogeneous group of tumours, of which $90 \%$ are of epithelial origin. Epithelial ovarian tumours are subclassified into various histological types, including ovarian mucinous tumours (OMTs), which account for $10-20 \%$ of all ovarian tumours. Of these OMTs $(10-20 \%)$ in humans, the positivity frequencies of MUC1 in OMTs range from 12 $-31.6 \%$ which is very low [55]. Muc1 is known to serve as a target molecule in the killing of breast cancer cells by the body's immune system [56-59] and hence is also assumed to be a good candidate for immunotherapy against human cancers [60]. So as to avoid being detected and killed by the immune system, the cancer cells can undergo epigenetic changes [61] such that they lose Muc1 expression or modulate its antigenicity [62-69]. Similarly, downregulation of Muc1 can also be induced in cancer cells subjected to anticancer drugs, which in turn might protect tumours against host's immunity $[70,71]$. It has also been seen in some cases that Muc1 is highly expressed in the normal mammary gland of an animal but not in a mammary tumour of the same animal, which suggests that in vivo factors could cause downregulation of Muc1 expression [72]. Similarly, the expression of MUC1 in breast cancer cells might also be linked with expression of other markers like HER2 [73-75].

Similar is the case with Her2. Cultured circulating tumour cells maintain discrete Her2+ and Her2subpopulations and these cells can interconvert spontaneously in vivo just within few cell doublings [76, 77]. There can be certain factors that selectively pressurise the tumour niche such that breast cancer cells in vivo acquire a change in their Her2 status [78, 79]. The cancer cells may express Her2 primarily, but there could be discordance as the same cells that are metastasizing or circulating in vivo may not express Her2 or vice-versa [80-87]. So, in principle, the Her2 status of cancer cells in distant regions like bone marrow is independent of the primary tumour [88]. Her$2 /$ neu antigen loss can actively occur in primary tumors (epigenetic changes) due to the neu-targeted antitumor immune responses, which might be a part of the selection process of a tumor variant that has reduced ability to induce danger signals [23, 43, 89-92]. Neu antigen-negative variants have been reported to be generated after neu-specific antibody therapy in a neu transgenic mice model of breast cancer [93], and a similar loss of Her2 is observed in humans with gastric or gastroesophageal cancer following trastuzumab therapy [94].

On similar grounds dysregulation of expression of cytokeratins is also possible in cancer cells. For example, downregulation of cytokeratin 18 in breast cancer cells is observed in some cases [95] and such dysregulation might also be triggered due to the effect of drugs [96]. The anti-tumour action drives the process of epithelial-mesenchymal transformation of cancer cells, causing downregulation of epithelial markers such as cytokeratins [97]. Downregulation of cytokeratin 18 in metastatic cancer cells in distant regions like bone marrow can also commonly occur [98]. Such dynamic nature of expression of different markers in cancer cells following dissemination, makes the immunohistochemical assessments of these cells quite challenging.

A similar level of difficulty exists with detection of breast cancer cells in preclinical rodent models of experimental metastasis. Cell line misidentification is known to be a common problem [99]. On these grounds, a case of misidentification of a widely studied cancer cell line, U87MG glioma, was recently reported when it was found that the DNA profile of the cell line obtained from ATCC was different from that of the original cells, raising doubts on the authenticity of this ATCC cell line [100]. Similarly, although Walker 256 rat breast cancer cell line is commonly believed to be of epithelial origin, an old study had reported that epithelial cell markers were absent in Walker 256 cells [101]. Walker 256 cells have also been suggested to be of hematopoietic origin and not of epithelial origin, which was substantiated by the authors findings that these cells grew as non-adherent clumps of cells indicative of a lymphoid / leukemia cell culture rather than the sheets observed with epithelial cell lines [101103]. Walker 256 cell tumour is also known to be able to give rise to a more fibroblastic cell line [104, 105]. It remains possible that Walker 256 cell line contains a heterogeneous population of different type of cells which are genetically programmed to change themselves from one state to other. For example, in vitro pure cultures of epithelial cells of Walker 256 tumour have been reported to transdifferentiate in vivo into tumours simulating fibrosarcoma [105]. Such cancer associated fibroblasts could be a cell state rather than a cell type, and origin of these cells could just be transdifferentiated epithelial cells [106]. Growth of epithelial components of Walker 256 tumour could be limited by the network of fibroblasts [107]. However, there is no specific marker for breast cancer associated 
fibroblasts [108]. On these grounds, several terms have been coined to address the cancer produced by the same Walker 256 cells, viz. carcinoma, adenocarcinoma, carcinosarcoma, sarcoma and fibrosarcoma [105, 109-114]. Techniques like local intraosseous injection of cancer cells in rodents are commonly used to experimentally simulate metastasis of cancer cells to distant regions like axial skeleton [115-123]. However, there can be remarkable differences in the expression levels of different markers expressed by the cancer cells colonising the distant regions like bones due to the possible phenotypic and genotypic changes occurring in the cancer cells after experimental engraftment. To obtain detailed insights into these changes, one will require to perform comparative genomic and proteomic assessments of cell line cultured in vitro and bone-colonising tumours developed in vivo in these pre-clinical models.

Although it is generally expected that cancer cells in the metastasised regions might be detected in the local lymph nodes, this might not always be the case [124]. Lymph node negative breast cancer cases in humans are common, and metastases of cancer cells to distant regions like bones without presence of these cells in the lymph nodes is not unexpected [125-131]. If there are any cells from afferent lymph that reach the lymph nodes, it remains possible that these cells can transverse the lymph nodes and enter the efferent lymph [132] and might be subsequently eliminated by the immune system. The cancer cells don't necessarily need to grow in the lymph nodes as the transnodal passage of cells might occur [133]. For example, the Walker 256 rat breast cancer cells can pass the lymph nodes and enter blood circulation and hence may not even grow in the lymph nodes as shown in female wistar rats [134].

Another minor challenge with immunohistochemical assessment of cancer cells in distant regions like bones could be the experimental artefact introduced by the process of decalcification typically required to soften the osseous tissue. Although EDTA is commonly used for decalcification of tissues like bones [135] and normally considered safe, it can have detrimental effects on the cancer cells colonising the bones, thereby posing difficulties in immunohistochemical detection of these metastasized cells [136-148].

Additionally, breast cancer cells can change in vivo such that they are present in a non-proliferative state and might possess stem-cell like characteristics [149153]. Transdifferentiation of cells from one cell type to another is a commonly observed phenomenon with cancer cells [154-164]. Transdifferentiated cells thus formed can still be malignant in nature [165-179]. Breast cancer cell lines can co-express several types of differentiation markers, leading to_aberrant multilineage transdifferentiation or lineage infidelity [180]. Hence, in the immunocompetent host, the possible dynamic nature of genotypic and phenotypic variations occurring in metastasized breast cancer cells, makes it difficult to immunohistochemically predict the molecular nature of metastasized tumours developed in distant tissues.

\section{CONFLICT OF INTEREST}

The author declares no conflict of interest.

\section{REFERENCES}

[1] Stelow EB, Yaziji H. Immunohistochemistry, carcinomas of unknown primary, and incidence rates. Seminars in diagnostic pathology 2018; 35: 143-152. https://doi.org/10.1053/j.semdp.2017.11.012

[2] Slade MJ, Coombes RC. The clinical significance of disseminated tumor cells in breast cancer. Nat Clin Prac Oncol 2007; 4: 30-41.

https://doi.org/10.1038/ncponc0685

[3] Allott EH, Geradts J, Sun X, Cohen SM, Zirpoli GR, Khoury T, Bshara W, Chen M, Sherman ME, Palmer JR, Ambrosone $\mathrm{CB}$, Olshan AF, Troester MA. Intratumoral heterogeneity as a source of discordance in breast cancer biomarker classification. Breast Cancer Research 2016; 18: 1-11. https://doi.org/10.1186/s13058-016-0725-1

[4] Bedard PL, Hansen AR, Ratain MJ, Siu LL. Tumour heterogeneity in the clinic. Nature 2013; 501: 355-364. https://doi.org/10.1038/nature12627

[5] Sturgeon CM, Duffy MJ, Stenman U-H, Lilja $H$, Brünner $N$, Chan DW, Babaian R, Bast RC, Dowell B, Esteva FJ, Haglund C, Harbeck N, Hayes DF, Holten-Andersen M, Klee GG, Lamerz R, Looijenga LH, Molina R, Nielsen HJ, Rittenhouse H, Semjonow A, Shih I-M, Sibley $P$, Sölétormos G, Stephan C, Sokoll L, Hoffman BR, Diamandis EP. National Academy of Clinical Biochemistry Laboratory Medicine Practice Guidelines for Use of Tumor Markers in Testicular, Prostate, Colorectal, Breast, and Ovarian Cancers. Clinical Chemistry 2008; 54: e11-e79.

[6] Olofsson MH, Ueno T, Pan Y, Xu R, Cai F, van der Kuip H, Muerdter TE, Sonnenberg M, Aulitzky WE, Schwarz S, Andersson E, Shoshan MC, Havelka AM, Toi M, Linder S. Cytokeratin-18 is a useful serum biomarker for early determination of response of breast carcinomas to chemotherapy. Clinical cancer research : an official journal of the American Association for Cancer Research 2007; 13: 3198-3206.

https://doi.org/10.1158/1078-0432.CCR-07-0009

[7] Buckley NE, Forde C, McArt DG, Boyle DP, Mullan PB, James JA, Maxwell $P$, McQuaid S, Salto-Tellez M. Quantification of HER2 heterogeneity in breast cancerimplications for identification of sub-dominant clones for personalised treatment. Scientific reports 2016; 6

[8] Kurozumi S, Padilla M, Kurosumi M, Matsumoto H, Inoue K Horiguchi J, Takeyoshi I, Oyama T, Ranger-Moore J, Allred DC, Dennis E, Nitta H. HER2 intratumoral heterogeneity analyses by concurrent HER2 gene and protein assessment for the prognosis of HER2 negative invasive breast cancer 
patients. Breast cancer research and treatment 2016; 158: 99-111.

https://doi.org/10.1007/s10549-016-3856-2

[9] Onsum MD, Geretti E, Paragas V, Kudla AJ, Moulis SP, Luus L, Wickham TJ, McDonagh CF, Macbeath G, Hendriks BS. Single-cell quantitative HER2 measurement identifies heterogeneity and distinct subgroups within traditionally defined HER2-positive patients. Am J Pathol 2013; 183: 1446-1460.

https://doi.org/10.1016/j.ajpath.2013.07.015

[10] Rahn JJ, Dabbagh L, Pasdar M, Hugh JC. The importance of MUC1 cellular localization in patients with breast carcinoma. Cancer 2001; 91: 1973-1982.

https://doi.org/10.1002/10970142(20010601)91:11<1973::AID-CNCR1222>3.0.CO;2-A

[11] Cimpean AM, Suciu C, Ceausu R, Tatucu D, Muresan AM, Raica M. Relevance of the immunohistochemical expression of cytokeratin 8/18 for the diagnosis and classification of breast cancer. Romanian journal of morphology and embryology $=$ Revue roumaine de morphologie et embryologie 2008; 49: 479-483.

[12] Orito T, Shinohara H, Okada Y, Mori M. Heterogeneity of Keratin Expression in Epithelial Tumor Cells of Adenolymphoma in Paraffin Sections. Pathology - Research and Practice 1989; 184: 600-608.

https://doi.org/10.1016/S0344-0338(89)80165-7

[13] Lichy JH, Dalbegue F, Zavar M, Washington C, Tsai MM, Sheng Z-M, Taubenberger JK. Genetic Heterogeneity in Ductal Carcinoma of the Breast. Laboratory investigation; a journal of technical methods and pathology 2000; 80: 291301.

https://doi.org/10.1038/labinvest.3780034

[14] Denisov EV, Litviakov NV, Zavyalova MV, Perelmuter VM, Vtorushin SV, Tsyganov MM, Gerashchenko TS, Garbukov EY, Slonimskaya EM, Cherdyntseva NV. Intratumoral morphological heterogeneity of breast cancer: neoadjuvant chemotherapy efficiency and multidrug resistance gene expression. Scientific reports 2014; 4: 4709.

https://doi.org/10.1038/srep04709

[15] Hiley C, de Bruin EC, McGranahan N, Swanton C. Deciphering intratumor heterogeneity and temporal acquisition of driver events to refine precision medicine. Genome biology 2014; 15: 453.

https://doi.org/10.1186/s13059-014-0453-8

[16] Badve S, Nakshatri H. Breast-cancer stem cells\&\#x2014; beyond semantics. The Lancet Oncology 2012; 13: e43-e48. https://doi.org/10.1016/S1470-2045(11)70191-7

[17] Marusyk A, Almendro V, Polyak K. Intra-tumour heterogeneity: a looking glass for cancer? Nature reviews Cancer 2012; 12: 323-334. https://doi.org/10.1038/nrc3261

[18] Whitescarver J. Problems of In vitro Culture of Human Mammary Tumor Cells. Journal of Investigative Dermatology 1974; 63: 58-64. https://doi.org/10.1111/1523-1747.ep12678088

[19] Hanahan D, Weinberg Robert A. Hallmarks of Cancer: The Next Generation. Cell 2011; 144: 646-674. https://doi.org/10.1016/j.cell.2011.02.013

[20] Negrini S, Gorgoulis VG, Halazonetis TD. Genomic instability [mdash] an evolving hallmark of cancer. Nat Rev Mol Cell Biol 2010; 11: 220-228. https://doi.org/10.1038/nrm2858

[21] Ferguson LR, Chen $H$, Collins AR, Connell M, Damia G, Dasgupta S, Malhotra M, Meeker AK, Amedei A, Amin A, Ashraf SS, Aquilano K, Azmi AS, Bhakta D, Bilsland A, Boosani CS, Chen S, Ciriolo MR, Fujii H, Guha G, Halicka D, Helferich WG, Keith WN, Mohammed SI, Niccolai E, Yang X, Honoki K, Parslow VR, Prakash S, Rezazadeh S, Shackelford RE, Sidransky D, Tran PT, Yang ES, Maxwell CA. Genomic instability in human cancer: Molecular insights and opportunities for therapeutic attack and prevention through diet and nutrition. Seminars in Cancer Biology 2015; 35: S5-S24.

https://doi.org/10.1016/j.semcancer.2015.03.005

[22] Dunn GP, Bruce AT, Ikeda H, Old LJ, Schreiber RD. Cancer immunoediting: from immunosurveillance to tumor escape. Nature immunology 2002; 3: 991-998.

https://doi.org/10.1038/ni1102-991

[23] Kmieciak M, Knutson KL, Dumur CI, Manjili MH. HER-2/neu antigen loss and relapse of mammary carcinoma are actively induced by $T$ cell-mediated anti-tumor immune responses. European journal of immunology 2007; 37: 675-685. https://doi.org/10.1002/eji.200636639

[24] Dunn GP, Old LJ, Schreiber RD. The three Es of cancer immunoediting. Annual review of immunology 2004; 22: 329360.

https://doi.org/10.1146/annurev.immunol.22.012703.104803

[25] Mohme M, Riethdorf S, Pantel K. Circulating and disseminated tumour cells [mdash] mechanisms of immune surveillance and escape. Nat Rev Clin Oncol 2016; advance online publication.

[26] Sanchez-Perez L, Kottke T, Diaz RM, Ahmed A, Thompson J, Chong $\mathrm{H}$, Melcher A, Holmen S, Daniels G, Vile RG. Potent Selection of Antigen Loss Variants of B16 Melanoma following Inflammatory Killing of Melanocytes In vivo. Cancer research 2005; 65: 2009-2017. https://doi.org/10.1158/0008-5472.CAN-04-3216

[27] Liu K, Caldwell SA, Abrams SI. Immune selection and emergence of aggressive tumor variants as negative consequences of Fas-mediated cytotoxicity and altered IFNgamma-regulated gene expression. Cancer research 2005; 65: 4376-4388.

https://doi.org/10.1158/0008-5472.CAN-04-4269

[28] Beatty GL, Paterson Y. IFN-gamma can promote tumor evasion of the immune system in vivo by down-regulating cellular levels of an endogenous tumor antigen. Journal of immunology (Baltimore, Md: 1950) 2000; 165: 5502-5508.

[29] Beatty GL, Paterson Y. Regulation of tumor growth by IFNgamma in cancer immunotherapy. Immunologic research 2001; $24: 201-210$

https://doi.org/10.1385/IR:24:2:201

[30] Singh A, Sirohi B, Gupta S. Biomarkers in Breast Cancer and the Implications of Their Discordance. Current Breast Cancer Reports 2013; 5: 266-274. https://doi.org/10.1007/s12609-013-0126-8

[31] Thompson AM, Jordan LB, Quinlan P, Anderson E, Skene A Dewar JA, Purdie CA. Prospective comparison of switches in biomarker status between primary and recurrent breast cancer: the Breast Recurrence In Tissues Study (BRITS). Breast cancer research : BCR 2010; 12: R92.

[32] Aktas B, Kasimir-Bauer S, Müller V, Janni W, Fehm T, Wallwiener D, Pantel K, Tewes M. Comparison of the HER2, estrogen and progesterone receptor expression profile of primary tumor, metastases and circulating tumor cells in metastatic breast cancer patients. BMC cancer 2016; 16

[33] Somlo G, Lau SK, Frankel P, Hsieh HB, Liu X, Yang L, Krivacic R, Bruce RH. Multiple biomarker expression on circulating tumor cells in comparison to tumor tissues from primary and metastatic sites in patients with locally advanced/inflammatory, and stage IV breast cancer, using a novel detection technology. Breast cancer research and treatment 2011; 128: 155-163. https://doi.org/10.1007/s10549-011-1508-0

[34] Millner LM, Linder MW, Valdes R, Jr. Circulating tumor cells: a review of present methods and the need to identify heterogeneous phenotypes. Ann Clin Lab Sci 2013; 43: 295304. 
[35] Zhang C, Guan Y, Sun Y, Ai D, Guo Q. Tumor heterogeneity and circulating tumor cells. Cancer letters 2016; 374: 216223. https://doi.org/10.1016/j.canlet.2016.02.024

[36] Vlems FA, Ruers TJM, Punt CJA, Wobbes T, van Muijen GNP. Relevance of disseminated tumour cells in blood and bone marrow of patients with solid epithelial tumours in perspective. European Journal of Surgical Oncology (EJSO) 2003; 29: 289-302.

https://doi.org/10.1053/ejso.2002.1394

[37] Deng G, Krishnakumar S, Powell AA, Zhang H, Mindrinos MN, Telli ML, Davis RW, Jeffrey SS. Single cell mutational analysis of PIK3CA in circulating tumor cells and metastases in breast cancer reveals heterogeneity, discordance, and mutation persistence in cultured disseminated tumor cells from bone marrow. BMC cancer 2014; 14: 456. https://doi.org/10.1186/1471-2407-14-456

[38] Fehm T, Krawczyk N, Solomayer E-F, Becker-Pergola G, Dürr-Störzer $S$, Neubauer $H$, Seeger $H$, Staebler A, Wallwiener D, Becker S. ERalpha-status of disseminated tumour cells in bone marrow of primary breast cancer patients. Breast Cancer Research 2008; 10: 1-8. https://doi.org/10.1186/bcr1869

[39] El Nemr Esmail RS, El Farouk Abdel-Salam LO, Abd El Ellah MM. Could the Breast Prognostic Biomarker Status Change During Disease Progression? An Immunohistochemical Comparison between Primary Tumors and Synchronous Nodal Metastasis. Asian Pacific journal of cancer prevention : APJCP 2015; 16: 4317-4321.

https://doi.org/10.7314/APJCP.2015.16.10.4317

[40] Hanagiri T, Shigematsu Y, Shinohara S, Takenaka M, Oka S, Chikaishi Y, Nagata Y, Baba T, Uramoto H, So T, Yamada S. Clinical significance of expression of cancer/testis antigen and down-regulation of HLA class-I in patients with stage I non-small cell lung cancer. Anticancer research 2013; 33: 2123-2128.

[41] Mendez R, Ruiz-Cabello F, Rodriguez T, Del Campo A, Paschen A, Schadendorf D, Garrido F. Identification of different tumor escape mechanisms in several metastases from a melanoma patient undergoing immunotherapy. Cancer immunology, immunotherapy : CII 2007; 56: 88-94. https://doi.org/10.1007/s00262-006-0166-2

[42] Rivoltini L, Carrabba M, Huber V, Castelli C, Novellino L, Dalerba P, Mortarini R, Arancia G, Anichini A, Fais S, Parmiani G. Immunity to cancer: attack and escape in $T$ lymphocyte-tumor cell interaction. Immunological reviews 2002; 188: 97-113. https://doi.org/10.1034/j.1600-065X.2002.18809.x

[43] Knutson KL, Lu H, Stone B, Reiman JM, Behrens MD, Prosperi CM, Gad EA, Smorlesi A, Disis ML. Immunoediting of cancers may lead to epithelial to mesenchymal transition. Journal of immunology (Baltimore, Md: 1950) 2006; 177: 1526-1533.

https://doi.org/10.4049/jimmunol.177.3.1526

[44] Gorges TM, Tinhofer I, Drosch M, Röse L, Zollner TM, Krahn $\mathrm{T}$, von Ahsen $\mathrm{O}$. Circulating tumour cells escape from EpCAM-based detection due to epithelial-to-mesenchymal transition. BMC cancer 2012; 12: 1-13.

https://doi.org/10.1186/1471-2407-12-178

[45] Larue L, Bellacosa A. Epithelial-mesenchymal transition in development and cancer: role of phosphatidylinositol 3[prime] kinase//AKT pathways. Oncogene 2005; 24: 74437454.

https://doi.org/10.1038/sj.onc.1209091

[46] Voulgari A, Pintzas A. Epithelial-mesenchymal transition in cancer metastasis: Mechanisms, markers and strategies to overcome drug resistance in the clinic. Biochimica et Biophysica Acta (BBA) - Reviews on Cancer 2009; 1796: 7590.

https://doi.org/10.1016/j.bbcan.2009.03.002
[47] Foroni C, Broggini M, Generali D, Damia G. Epithelialmesenchymal transition and breast cancer: Role, molecular mechanisms and clinical impact. Cancer treatment reviews 2012; 38: 689-697.

https://doi.org/10.1016/j.ctrv.2011.11.001

[48] Wu Y, Sarkissyan M, Vadgama J. Epithelial-Mesenchymal Transition and Breast Cancer. Journal of Clinical Medicine 2016; 5: 13. https://doi.org/10.3390/jcm5020013

[49] Bill R, Christofori G. The relevance of EMT in breast cancer metastasis: Correlation or causality? FEBS letters 2015; 589: 1577-1587. https://doi.org/10.1016/j.febslet.2015.05.002

[50] Palma CdS, Grassi ML, Thomé CH, Ferreira GA, Albuquerque D, Pinto MT, Melo FUF, Kashima S, Covas DT, Pitteri SJ, Faca VM. Proteomic analysis of epithelial to mesenchymal transition reveals crosstalk between SNAIL and HDAC1 in breast cancer cells. Molecular \& Cellular Proteomics 2016

[51] Duffy MJ, Evoy D, McDermott EW. CA 15-3: Uses and limitation as a biomarker for breast cancer. Clinica Chimica Acta 2010; 411: 1869-1874. https://doi.org/10.1016/j.cca.2010.08.039

[52] DeSouza MM, Mani SK, Julian J, Carson DD. Reduction of mucin-1 expression during the receptive phase in the rat uterus. Biology of reproduction 1998; 58: 1503-1507. https://doi.org/10.1095/biolreprod58.6.1503

[53] Horne AW, Lalani EN, Margara RA, White JO. The effects of sex steroid hormones and interleukin-1-beta on MUC1 expression in endometrial epithelial cell lines. Reproduction (Cambridge, England) 2006; 131: 733-742. https://doi.org/10.1530/rep.1.00883

[54] Leong CF, Raudhawati O, Cheong SK, Sivagengei K, Noor Hamidah $\mathrm{H}$. Epithelial membrane antigen (EMA) or MUC1 expression in monocytes and monoblasts. Pathology 2003; 35: 422-427. https://doi.org/10.1080/00313020310001602576

[55] Wang J, El-Bahrawy M. Expression profile of mucins (MUC1, MUC2, MUC5AC, and MUC6) in ovarian mucinous tumours: changes in expression from benign to malignant tumours. Histopathology 2015; 66: 529-535. https://doi.org/10.1111/his.12578

[56] Barnd DL, Lan MS, Metzgar RS, Finn OJ. Specific, major histocompatibility complex-unrestricted recognition of tumorassociated mucins by human cytotoxic T cells. Proceedings of the National Academy of Sciences of the United States of America 1989; 86: 7159-7163. https://doi.org/10.1073/pnas.86.18.7159

[57] Agrawal B, Reddish MA, Longenecker BM. In vitro induction of MUC-1 peptide-specific type $1 \mathrm{~T}$ lymphocyte and cytotoxic $\mathrm{T}$ lymphocyte responses from healthy multiparous donors. Journal of immunology (Baltimore, Md: 1950) 1996; 157: 2089-2095.

[58] Pecher G, Finn OJ. Induction of cellular immunity in chimpanzees to human tumor-associated antigen mucin by vaccination with MUC-1 cDNA-transfected Epstein-Barr virus-immortalized autologous $B$ cells. Proceedings of the National Academy of Sciences of the United States of America 1996; 93: 1699-1704. https://doi.org/10.1073/pnas.93.4.1699

[59] Magarian-Blander J, Ciborowski P, Hsia S, Watkins SC, Finn OJ. Intercellular and intracellular events following the MHCunrestricted TCR recognition of a tumor-specific peptide epitope on the epithelial antigen MUC1. Journal of immunology (Baltimore, Md: 1950) 1998; 160: 3111-3120.

[60] Akagi J, Hodge JW, McLaughlin JP, Gritz L, Mazzara G, Kufe D, Schlom J, Kantor JA. Therapeutic antitumor response after immunization with an admixture of recombinant vaccinia viruses expressing a modified MUC1 gene and the murine 
T-cell costimulatory molecule B7. Journal of immunotherapy (Hagerstown, Md: 1997) 1997; 20: 38-47. https://doi.org/10.1097/00002371-199701000-00004

[61] Wachowska M, Muchowicz A, Golab J. Targeting Epigenetic Processes in Photodynamic Therapy-Induced Anticancer Immunity. Frontiers in Oncology 2015; 5

[62] Kontani K, Taguchi O, Narita T, Izawa M, Hiraiwa N, Zenita $\mathrm{K}$, Takeuchi T, Murai H, Miura S, Kannagi R. Modulation of MUC1 mucin as an escape mechanism of breast cancer cells from autologous cytotoxic T-lymphocytes. British Journal of Cancer 2001; 84: 1258-1264. https://doi.org/10.1054/bjoc.2000.1744

[63] Lakshminarayanan V, Supekar NT, Wei J, McCurry DB, Dueck AC, Kosiorek HE, Trivedi PP, Bradley JM, Madsen CS, Pathangey LB, Hoelzinger DB, Wolfert MA, Boons GJ, Cohen PA, Gendler SJ. MUC1 Vaccines, Comprised of Glycosylated or Non-Glycosylated Peptides or TumorDerived MUC1, Can Circumvent Immunoediting to Control Tumor Growth in MUC1 Transgenic Mice. PloS one 2016; 11: e0145920.

[64] Anandkumar A, Devaraj $H$. Tumour immunomodulation: mucins in resistance to initiation and maturation of immune response against tumours. Scandinavian journal of immunology 2013; 78: 1-7. https://doi.org/10.1111/sji.12019

[65] Oudejans JJ, ten Berge RL, Meijer C. Immune escape mechanisms in ALCL. Journal of clinical pathology 2003; 56: 423-425.

https://doi.org/10.1136/jcp.56.6.423

[66] Mukherjee P, Ginardi AR, Madsen CS, Sterner CJ, Adriance MC, Tevethia MJ, Gendler SJ. Mice with Spontaneous Pancreatic Cancer Naturally Develop MUC-1-Specific CTLs That Eradicate Tumors When Adoptively Transferred. The Journal of Immunology 2000; 165: 3451-3460. https://doi.org/10.4049/jimmunol.165.6.3451

[67] Villalba M, Rathore MG, Lopez-Royuela N, Krzywinska E, Garaude J, Allende-Vega N. From tumor cell metabolism to tumor immune escape. The international journal of biochemistry \& cell biology 2013; 45: 106-113.

https://doi.org/10.1016/j.biocel.2012.04.024

[68] Julian J, Dharmaraj N, Carson DD. MUC1 is a substrate for gamma-secretase. Journal of cellular biochemistry 2009; 108: 802-815.

https://doi.org/10.1002/jcb.22292

[69] Sanchez C, Chan R, Bajgain P, Rambally S, Palapattu G, Mims M, Rooney CM, Leen AM, Brenner MK, Vera JF. Combining T-cell immunotherapy and anti-androgen therapy for prostate cancer. Prostate cancer and prostatic diseases 2013; 16: 123-131, s121.

[70] Roulois D, Blanquart C, Panterne C, Gueugnon F, Gregoire $\mathrm{M}$, Fonteneau JF. Downregulation of MUC1 expression and its recognition by $\mathrm{CD} 8(+) \mathrm{T}$ cells on the surface of malignant pleural mesothelioma cells treated with HDACi. European journal of immunology 2012; 42: 783-789. https://doi.org/10.1002/eji.201141800

[71] Dorn DC, Harnack U, Pecher G. Down-regulation of the human tumor antigen mucin by gemcitabine on the pancreatic cancer cell line capan-2. Anticancer research 2004; 24: 821-825.

[72] Adriance MC, Gendler SJ. Downregulation of Muc1 in MMTV-c-Neu tumors. Oncogene 2004; 23: 697-705. https://doi.org/10.1038/sj.onc.1207165

[73] Raina D, Uchida $Y$, Kharbanda A, Rajabi H, Panchamoorthy G, Jin C, Kharbanda S, Scaltriti M, Baselga J, Kufe D. Targeting the MUC1-C oncoprotein downregulates HER2 activation and abrogates trastuzumab resistance in breast cancer cells. Oncogene 2014; 33: 3422-3431.

https://doi.org/10.1038/onc.2013.308
[74] Li Y, Yu WH, Ren J, Chen W, Huang L, Kharbanda S, Loda $M$, Kufe D. Heregulin targets gamma-catenin to the nucleolus by a mechanism dependent on the DF3/MUC1 oncoprotein. Molecular cancer research : MCR 2003; 1: 765-775.

[75] Kufe DW. MUC1-C oncoprotein as a target in breast cancer: activation of signaling pathways and therapeutic approaches. Oncogene 2013; 32: 1073-1081. https://doi.org/10.1038/onc.2012.158

[76] Jordan NV, Bardia A, Wittner BS, Benes C, Ligorio M, Zheng Y, Yu M, Sundaresan TK, Licausi JA, Desai R, O'Keefe RM, Ebright RY, Boukhali M, Sil S, Onozato ML, lafrate AJ, Kapur R, Sgroi D, Ting DT, Toner M, Ramaswamy S, Haas W, Maheswaran S, Haber DA. HER2 expression identifies dynamic functional states within circulating breast cancer cells. Nature 2016; 537: 102-106. https://doi.org/10.1038/nature19328

[77] Wood KC. Two faces of circulating breast cancer cells. Science Translational Medicine 2016; 8: 356ec149$356 \mathrm{ec} 149$.

[78] Arteaga Carlos L, Engelman Jeffrey A. ERBB Receptors: From Oncogene Discovery to Basic Science to MechanismBased Cancer Therapeutics. Cancer Cell 2014; 25: 282-303. https://doi.org/10.1016/j.ccr.2014.02.025

[79] Krawczyk N, Banys M, Neubauer H, Solomayer EF, Gall C Hahn M, Becker S, Bachmann R, Wallwiener D, Fehm T. HER2 status on persistent disseminated tumor cells after adjuvant therapy may differ from initial HER2 status on primary tumor. Anticancer research 2009; 29: 4019-4024.

[80] Houssami N, Macaskill P, Balleine RL, Bilous M, Pegram MD. HER2 discordance between primary breast cancer and its paired metastasis: tumor biology or test artefact? Insights through meta-analysis. Breast cancer research and treatment 2011; 129: 659-674. https://doi.org/10.1007/s10549-011-1632-x

[81] Turner NH, Di Leo A. HER2 discordance between primary and metastatic breast cancer: assessing the clinical impact. Cancer treatment reviews 2013; 39: 947-957.

https://doi.org/10.1016/j.ctrv.2013.05.003

[82] Bidard F-C, Peeters DJ, Fehm T, Nolé F, Gisbert-Criado R, Mavroudis D, Grisanti S, Generali D, Garcia-Saenz JA Stebbing J, Caldas C, Gazzaniga P, Manso L, Zamarchi R, de Lascoiti AF, De Mattos-Arruda L, Ignatiadis M, Lebofsky $\mathrm{R}$, van Laere SJ, Meier-Stiegen F, Sandri M-T, VidalMartinez J, Politaki E, Consoli F, Bottini A, Diaz-Rubio E, Krell J, Dawson S-J, Raimondi C, Rutten A, Janni W, Munzone E, Carañana V, Agelaki S, Almici C, Dirix L, Solomayer E-F, Zorzino L, Johannes H, Reis-Filho JS, Pantel $\mathrm{K}$, Pierga J-Y, Michiels S. Clinical validity of circulating tumour cells in patients with metastatic breast cancer: a pooled analysis of individual patient data. The Lancet Oncology 2014; 15: 406-414.

https://doi.org/10.1016/S1470-2045(14)70069-5

[83] Krishnamurthy S, Bischoff F, Ann Mayer J, Wong K, Pham T, Kuerer $\mathrm{H}$, Lodhi A, Bhattacharyya A, Hall C, Lucci A. Discordance in HER2 gene amplification in circulating and disseminated tumor cells in patients with operable breast cancer. Cancer medicine 2013; 2: 226-233. https://doi.org/10.1002/cam4.70

[84] Jäger BAS, Finkenzeller C, Bock C, Majunke L, Jueckstock JK, Andergassen U, Neugebauer JK, Pestka A, Friedl TWP, Jeschke U, Janni W, Doisneau-Sixou SF, Rack BK. Estrogen Receptor and HER2 Status on Disseminated Tumor Cells and Primary Tumor in Patients with Early Breast Cancer. Translational Oncology 2015; 8: 509-516. https://doi.org/10.1016/..tranon.2015.11.009

[85] Pusztai L, Viale G, Kelly CM, Hudis CA. Estrogen and HER-2 Receptor Discordance Between Primary Breast Cancer and Metastasis. The Oncologist 2010; 15: 1164-1168. https://doi.org/10.1634/theoncologist.2010-0059 
[86] St. Romain P, Madan R, Tawfik OW, Damjanov I, Fan F. Organotropism and prognostic marker discordance in distant metastases of breast carcinoma: fact or fiction? A clinicopathologic analysis. Human Pathology 2012; 43: 398404.

https://doi.org/10.1016/j.humpath.2011.05.009

[87] Sighoko D, Liu J, Hou N, Gustafson P, Huo D. Discordance in Hormone Receptor Status Among Primary, Metastatic, and Second Primary Breast Cancers: Biological Difference or Misclassification? Oncologist 2014; 19: 592-601. https://doi.org/10.1634/theoncologist.2013-0427

[88] Hartkopf AD, Banys M, Meier-Stiegen F, Hahn M, Röhm C, Hoffmann J, Helms G, Taran FA, Wallwiener M, Walter C, Neubauer $\mathrm{H}$, Wallwiener D, Fehm T. The HER2 status of disseminated tumor cells in the bone marrow of early breast cancer patients is independent from primary tumor and predicts higher risk of relapse. Breast cancer research and treatment 2013; 138: 509-517. https://doi.org/10.1007/s10549-013-2470-9

[89] Worschech A, Kmieciak M, Knutson KL, Bear HD, Szalay AA, Wang E, Marincola FM, Manjili MH. Signatures associated with rejection or recurrence in HER-2/neu-positive mammary tumors. Cancer research 2008; 68: 2436-2446. https://doi.org/10.1158/0008-5472.CAN-07-6822

[90] Manjili MH, Arnouk H, Knutson KL, Kmieciak M, Disis ML, Subjeck JR, Kazim AL. Emergence of immune escape variant of mammary tumors that has distinct proteomic profile and a reduced ability to induce "danger signals". Breast cancer research and treatment 2006; 96: 233-241. https://doi.org/10.1007/s10549-005-9044-4

[91] Kmieciak M, Morales JK, Morales J, Bolesta E, Grimes M, Manjili $\mathrm{MH}$. Danger signals and nonself entity of tumor antigen are both required for eliciting effective immune responses against HER-2/neu positive mammary carcinoma: implications for vaccine design. Cancer immunology, immunotherapy : Cll 2008; 57: 1391-1398. https://doi.org/10.1007/s00262-008-0475-8

[92] Marth C, Muller-Holzner E, Greiter E, Cronauer MV, Zeimet AG, Doppler W, Eibl B, Hynes NE, Daxenbichler G. Gammainterferon reduces expression of the protooncogene c-erbB-2 in human ovarian carcinoma cells. Cancer research 1990; 50: 7037-7041.

[93] Knutson KL, Almand B, Dang Y, Disis ML. Neu antigennegative variants can be generated after neu-specific antibody therapy in neu transgenic mice. Cancer research 2004; 64: 1146-1151.

https://doi.org/10.1158/0008-5472.CAN-03-0173

[94] Pietrantonio F, Caporale M, Morano F, Scartozzi M, Gloghini A, De Vita F, Giommoni E, Fornaro L, Aprile G, Melisi D, Berenato R, Mennitto A, Volpi CC, Laterza MM, Pusceddu V, Antonuzzo L, Vasile E, Ongaro E, Simionato F, de Braud F, Torri V, Di Bartolomeo M. HER2 loss in HER2-positive gastric or gastroesophageal cancer after trastuzumab therapy: Implication for further clinical research. Int J Cancer 2016; 139: 2859-2864.

https://doi.org/10.1002/ijc.30408

[95] Woelfle U, Sauter G, Santjer S, Brakenhoff R, Pantel K. Down-regulated expression of cytokeratin 18 promotes progression of human breast cancer. Clinical cancer research : an official journal of the American Association for Cancer Research 2004; 10: 2670-2674. https://doi.org/10.1158/1078-0432.CCR-03-0114

[96] Yin B, Zhang M, Zeng Y, Li Y, Zhang C, Song Y. Downregulation of cytokeratin 18 is associated with paclitaxelresistance and tumor aggressiveness in prostate cancer. International journal of oncology 2016; 48: 17301736. https://doi.org/10.3892/ijo.2016.3396

[97] Mego M, Mani SA, Lee BN, Li C, Evans KW, Cohen EN, Gao $H$, Jackson SA, Giordano A, Hortobagyi GN, Cristofanilli M,
Lucci A, Reuben JM. Expression of epithelial-mesenchymal transition-inducing transcription factors in primary breast cancer: The effect of neoadjuvant therapy. Int $\mathrm{J}$ Cancer 2012; 130: 808-816

https://doi.org/10.1002/ijc.26037

[98] Pantel K, Schlimok G, Angstwurm M, Weckermann D, Schmaus W, Gath H, Passlick B, Izbicki JR, Riethmuller G. Methodological analysis of immunocytochemical screening for disseminated epithelial tumor cells in bone marrow. Journal of hematotherapy 1994; 3: 165-173. https://doi.org/10.1089/scd.1.1994.3.165

[99] Yu M, Selvaraj SK, Liang-Chu MMY, Aghajani S, Busse M, Yuan J, Lee G, Peale F, Klijn C, Bourgon R, Kaminker JS, Neve RM. A resource for cell line authentication, annotation and quality control. Nature 2015; 520: 307-311. https://doi.org/10.1038/nature14397

[100] Allen M, Bjerke M, Edlund $H$, Nelander S, Westermark B. Origin of the U87MG glioma cell line: Good news and bad news. Science Translational Medicine 2016; 8: 354re353354 re353.

[101] Simpkins H, Lehman JM, Mazurkiewicz JE, Davis BH. A morphological and phenotypic analysis of Walker 256 cells. Cancer research 1991; 51: 1334-1338.

[102] Pavlaki M, Giannopoulou E, Niarakis A, Ravazoula P, Aletras AJ. Walker 256 cancer cells secrete tissue inhibitor of metalloproteinase-free metalloproteinase-9. Molecular and Cellular Biochemistry 2009; 328: 189-199. https://doi.org/10.1007/s11010-009-0089-2

[103] Campos CBL, Degasperi GR, Pacífico DS, Alberici LC, Carreira RS, Guimarães F, Castilho RF, Vercesi AE. Ibuprofen-induced Walker 256 tumor cell death: cytochrome $C$ release from functional mitochondria and enhancement by calcineurin inhibition. Biochemical pharmacology 2004; 68: 2197-2206.

https://doi.org/10.1016/j.bcp.2004.08.006

[104] Meyers RL. Studies on tumor antigens of the Walker 256 carcinosarcoma. Immunochemistry 1975; 12: 589-595. https://doi.org/10.1016/0019-2791(75)90091-9

[105] Earle WR. A Study of the Walker Rat Mammary Carcinoma 256 , in vivo and in vitro. The American Journal of Cancer 1935; 24: 566-612.

[106] Madar S, Goldstein I, Rotter V. 'Cancer associated fibroblasts'--more than meets the eye. Trends Mol Med 2013; 19: 447-453. https://doi.org/10.1016/j.molmed.2013.05.004

[107] Iwamori S. In vitro interactions between tumor cells and fibroblasts derived from the same individual. Gan 1966; 57 : 477-489.

[108] Buchsbaum R, Oh S. Breast Cancer-Associated Fibroblasts: Where We Are and Where We Need to Go. Cancers 2016; 8 : 19. https://doi.org/10.3390/cancers8020019

[109] Knox RJ, Lydall DA, Friedlos F, Basham C, Rawlings CJ, Roberts JJ. The Walker 256 carcinoma: a cell type inherently sensitive only to those difunctional agents that can form DNA interstrand crosslinks. Mutation research 1991; 255: 227240.

https://doi.org/10.1016/0921-8777(91)90026-L

[110] Dolowy WC, Schrek R, Henson D, Cornet J, Brown E. Effects of Guinea-pig Serum on the Walker 256 Carcinosarcoma. Nature 1968; 218: 1028-1031. https://doi.org/10.1038/2181028a0

[111] Graham WP, 3rd, Tragus ET, Blakemore WS. The influence of osteolytic substances on the production of osseous metastases from Walker 256 sarcoma in rats. J Surg Oncol 1974; 6: 117-121.

https://doi.org/10.1002/jso.2930060205

[112] Xu J-Y, Jiang Y, Liu W, Huang Y-G. Calpain Inhibitor Reduces Cancer-induced Bone Pain Possibly Through 
Inhibition of Osteoclastogenesis in Rat Cancer-induced Bone Pain Model. 2015.

[113] Sawada S, Okajima S, Aiyama R, Nokata K, Furuta T, Yokokura T, Sugino E, Yamaguchi K, Miyasaka T. Synthesis and antitumor activity of 20(S)-camptothecin derivatives: carbamate-linked, water-soluble derivatives of 7-ethyl-10hydroxycamptothecin. Chemical \& pharmaceutical bulletin 1991; 39: 1446-1450. https://doi.org/10.1248/cpb.39.1446

[114] De-Angeli LC, Pocchiari F, Russi S, Tonolo A, Zurita VE, Ciaranfi E, Perin A. Effect of L-Asparaginase from Aspergillus terreus on Ascites Sarcoma in the Rat. Nature 1970; 225: 549-550. https://doi.org/10.1038/225549a0

[115] Kaan TK, Yip PK, Patel S, Davies M, Marchand F, Cockayne DA, Nunn PA, Dickenson AH, Ford AP, Zhong Y, Malcangio $M$, McMahon SB. Systemic blockade of $P 2 X 3$ and $P 2 X 2 / 3$ receptors attenuates bone cancer pain behaviour in rats. Brain : a journal of neurology 2010; 133: 2549-2564. https://doi.org/10.1093/brain/awq194

[116] Liu H, Liu Z, Du J, He J, Lin P, Amini B, Starbuck MW, Novane N, Shah JJ, Davis RE, Hou J, Gagel RF, Yang J. Thymidine phosphorylase exerts complex effects on bone resorption and formation in myeloma. Science Translational Medicine 2016; 8: 353ra113-353ra113.

[117] Zhou JZ, Riquelme MA, Gu S, Kar R, Gao X, Sun L, Jiang JX. Osteocytic connexin hemichannels suppress breast cancer growth and bone metastasis. Oncogene 2016; 35: 5597-5607. https://doi.org/10.1038/onc.2016.101

[118] Xu Y, Liu J, He M, Liu R, Belegu V, Dai P, Liu W, Wang W, Xia QJ, Shang FF, Luo CZ, Zhou X, Liu S, McDonald J, Liu J, Zuo YX, Liu F, Wang TH. Mechanisms of PDGF siRNAmediated inhibition of bone cancer pain in the spinal cord. Scientific reports 2016; 6: 27512. https://doi.org/10.1038/srep27512

[119] Taipaleenmäki H, Browne G, Akech J, Zustin J, van Wijnen AJ, Stein JL, Hesse E, Stein GS, Lian JB. Targeting of Runx2 by miR-135 and miR-203 Impairs Progression of Breast Cancer and Metastatic Bone Disease. Cancer research 2015; 75: 1433-1444.

https://doi.org/10.1158/0008-5472.CAN-14-1026

[120] Torrano V, Valcarcel-Jimenez L, Cortazar AR, Liu X, Urosevic J, Castillo-Martin M, Fernandez-Ruiz S, Morciano G, Caro-Maldonado A, Guiu M, Zuniga-Garcia P, Graupera $M$, Bellmunt A, Pandya P, Lorente M, Martin-Martin N, David Sutherland J, Sanchez-Mosquera P, Bozal-Basterra L, Zabala-Letona A, Arruabarrena-Aristorena A, Berenguer A, Embade N, Ugalde-Olano A, Lacasa-Viscasillas I, LoizagaIriarte A, Unda-Urzaiz M, Schultz N, Aransay AM, SanzMoreno V, Barrio R, Velasco G, Pinton P, Cordon-Cardo C, Locasale JW, Gomis RR, Carracedo A. The metabolic coregulator PGC1[alpha] suppresses prostate cancer metastasis. Nature cell biology 2016; 18: 645-656. https://doi.org/10.1038/ncb3357

[121] Graham TJ, Box G, Tunariu N, Crespo M, Spinks TJ, Miranda S, Attard G, de Bono J, Eccles SA, Davies FE, Robinson SP. Preclinical Evaluation of Imaging Biomarkers for Prostate Cancer Bone Metastasis and Response to Cabozantinib. Journal of the National Cancer Institute 2014

[122] Trotter TN, Li M, Pan Q, Peker D, Rowan PD, Li J, Zhan F, Suva LJ, Javed A, Yang Y. Myeloma cell-derived Runx2 promotes myeloma progression in bone. Blood 2015; 125: 3598-3608. https://doi.org/10.1182/blood-2014-12-613968

[123] Niu Y, Altuwaijri S, Lai KP, Wu CT, Ricke WA, Messing EM, Yao J, Yeh S, Chang C. Androgen receptor is a tumor suppressor and proliferator in prostate cancer. Proceedings of the National Academy of Sciences of the United States of America 2008; 105: 12182-12187.

https://doi.org/10.1073/pnas.0804700105
[124] Suva LJ, Griffin RJ, Makhoul I. Mechanisms of bone metastases of breast cancer. Endocr Relat Cancer 2009; 16: 703-713. https://doi.org/10.1677/ERC-09-0012

[125] Smid M, Wang Y, Klijn JG, Sieuwerts AM, Zhang Y, Atkins D, Martens JW, Foekens JA. Genes associated with breast cancer metastatic to bone. Journal of clinical oncology : official journal of the American Society of Clinical Oncology 2006; 24: 2261-2267.

https://doi.org/10.1200/JCO.2005.03.8802

[126] Polednak AP. Survival of Lymph Node-Negative Breast Cancer Patients in Relation to Number of Lymph Nodes Examined. Ann Surg 2003; 237: 163-167. https://doi.org/10.1097/01.SLA.0000048552.84451.C5

[127] He J, Wang H, Ma F, Feng F, Lin C, Qian H. Prognosis of lymph node-negative breast cancer: Association with clinicopathological factors and tumor associated gene expression. Oncol Lett 2014; 8: 1717-1724.

https://doi.org/10.3892/ol.2014.2339

[128] Braun S, Cevatli BS, Assemi C, Janni W, Kentenich CRM, Schindlbeck C, Rjosk D, Hepp F. Comparative Analysis of Micrometastasis to the Bone Marrow and Lymph Nodes of Node-Negative Breast Cancer Patients Receiving No Adjuvant Therapy. Journal of Clinical Oncology 2001; 19: 1468-1475.

https://doi.org/10.1200/JCO.2001.19.5.1468

[129] Mulligan AM, Pinnaduwage D, Bull SB, O'Malley FP, Andrulis IL. Prognostic effect of basal-like breast cancers is time dependent: evidence from tissue microarray studies on a lymph node-negative cohort. Clinical cancer research : an official journal of the American Association for Cancer Research 2008; 14: 4168-4174. https://doi.org/10.1158/1078-0432.CCR-07-4543

[130] Shen S, Sun Q, Liang Z, Cui X, Ren X, Chen H, Zhang X, Zhou Y. A Prognostic Model of Triple-Negative Breast Cancer Based on miR-27b-3p and Node Status. PloS one 2014; 9: e100664.

[131] Colleoni M, O'Neill A, Goldhirsch A, Gelber RD, Bonetti M, Thurlimann B, Price KN, Castiglione-Gertsch M, Coates AS, Lindtner J, Collins J, Senn HJ, Cavalli F, Forbes J, Gudgeon A, Simoncini E, Cortes-Funes $H$, Veronesi A, Fey $M$, Rudenstam CM. Identifying breast cancer patients at high risk for bone metastases. Journal of clinical oncology : official journal of the American Society of Clinical Oncology 2000; 18: 3925-3935.

https://doi.org/10.1200/JCO.2000.18.23.3925

[132] Fisher B, Fisher ER. Transmigration of Lymph Nodes by Tumor Cells. Science (New York, NY) 1966; 152: 1397-1398. https://doi.org/10.1126/science.152.3727.1397

[133] Hewitt HB, Blake E. Quantitative studies of translymphnodal passage of tumour cells naturally disseminated from a non immunogenic murine squamous carcinoma. British Journal of Cancer 1975; 31: 25-35. https://doi.org/10.1038/bjc.1975.4

[134] Madden RE, Gyure L. Translymphnodal passage of tumor cells. Oncology 1968; 22: 281-289. https://doi.org/10.1159/000224460

[135] Nakamura $H$, Sato $G$, Hirata $A$, Yamamoto $T$. Immunolocalization of matrix metalloproteinase-13 on bone surface under osteoclasts in rat tibia. Bone 2004; 34: 48-56. https://doi.org/10.1016/j.bone.2003.09.001

[136] Gertych A, Mohan S, Maclary S, Mohanty S, Wawrowsky K, Mirocha J, Balzer B, Knudsen BS. Effects of tissue decalcification on the quantification of breast cancer biomarkers by digital image analysis. Diagnostic Pathology 2014; 9

[137] Henderson-Jackson EB, Khalil FK. Pathology of Metastatic Tumors to Bone: Effects of Decalcification as 2016; 2. 
[138] Alers JC, Krijtenburg PJ, Vissers KJ, van Dekken H. Effect of bone decalcification procedures on DNA in situ hybridization and comparative genomic hybridization. EDTA is highly preferable to a routinely used acid decalcifier. The journal of histochemistry and cytochemistry : official journal of the Histochemistry Society 1999; 47: 703-710.

https://doi.org/10.1177/002215549904700512

[139] Amir E, Miller N, Geddie W, Freedman O, Kassam F, Simmons C, Oldfield M, Dranitsaris G, Tomlinson G, Laupacis A, Tannock IF, Clemons M. Prospective Study Evaluating the Impact of Tissue Confirmation of Metastatic Disease in Patients With Breast Cancer. Journal of Clinical Oncology 2012; 30: 587-592. https://doi.org/10.1200/JCO.2010.33.5232

[140] Bussolati G, Leonardo E. Technical pitfalls potentially affecting diagnoses in immunohistochemistry. Journal of clinical pathology 2008; 61: 1184-1192. https://doi.org/10.1136/jcp.2007.047720

[141] Erber WN, McLachlan J. Use of APAAP technique on paraffin wax embedded bone marrow trephines. Journal of clinical pathology 1989; 42: 1201-1205.

https://doi.org/10.1136/jcp.42.11.1201

[142] Falini B, Martelli MF, Tarallo F, Moir DJ, Cordell JL, Gatter KC, Loreti G, Stein H, Mason DY. Immunohistological analysis of human bone marrow trephine biopsies using monoclonal antibodies. British journal of haematology 1984; 56: 365-386.

https://doi.org/10.1111/j.1365-2141.1984.tb03968.x

[143] De Wolf-Peeters C. Bone marrow trephine interpretation: diagnostic utility and potential pitfalls. Histopathology 1991; 18: 489-493.

https://doi.org/10.1111/j.1365-2559.1991.tb01474.x

[144] Kozloff KM, Weissleder R, Mahmood U. Noninvasive optical detection of bone mineral. Journal of bone and mineral research : the official journal of the American Society for Bone and Mineral Research 2007; 22: 1208-1216. https://doi.org/10.1359/jbmr.070504

[145] Darvishian F, Singh B, Krauter S, Chiriboga L, Gangi MD, Melamed J. Impact of decalcification on receptor status in breast cancer. The breast journal 2011; 17: 689-691. https://doi.org/10.1111/j.1524-4741.2011.01168.x

[146] Hanna W, Barnes $P$, Berendt R, Chang M, Magliocco A, Mulligan A, Rees H, Miller N, Elavathil L, Gilks B, Pettigrew N, Pilavdzic D, SenGupta S. Testing for her2 in breast cancer: current pathology challenges faced in Canada. Current Oncology 2012; 19: 315-323.

https://doi.org/10.3747/co.19.1173

[147] Hoefnagel LDC, van de Vijver MJ, van Slooten HJ, Wesseling P, Wesseling J, Westenend PJ, Bart J, Seldenrijk CA, Nagtegaal ID, Oudejans J, van der Valk $P$, van der Groep P, de Vries EGE, van der Wall E, van Diest PJ. Receptor conversion in distant breast cancer metastases. Breast cancer research : BCR 2010; 12: R75. https://doi.org/10.1186/bcr2645

[148] Maclary SC, Mohanty SK, Bose S, Chung F, Balzer BL. Effect of Hydrochloric Acid Decalcification on Expression Pattern of Prognostic Markers in Invasive Breast Carcinomas. Appl Immunohistochem Mol Morphol 2016

[149] Kasimir-Bauer S, Reiter K, Aktas B, Bittner AK, Weber S, Keller T, Kimmig R, Hoffmann O. Different prognostic value of circulating and disseminated tumor cells in primary breast cancer: Influence of bisphosphonate intake? Scientific reports 2016; 6: 26355.

https://doi.org/10.1038/srep26355

[150] Balic M, Lin H, Young L, Hawes D, Giuliano A, McNamara G, Datar RH, Cote RJ. Most early disseminated cancer cells detected in bone marrow of breast cancer patients have a putative breast cancer stem cell phenotype. Clinical cancer research : an official journal of the American Association for Cancer Research 2006; 12: 5615-5621.

https://doi.org/10.1158/1078-0432.CCR-06-0169
[151] Reuben JM, Lee BN, Gao H, Cohen EN, Mego M, Giordano A, Wang X, Lodhi A, Krishnamurthy S, Hortobagyi GN, Cristofanilli M, Lucci A, Woodward WA. Primary breast cancer patients with high risk clinicopathologic features have high percentages of bone marrow epithelial cells with ALDH activity and CD44(+)CD24lo cancer stem cell phenotype. European journal of cancer (Oxford, England: 1990) 2011; 47: $1527-1536$.

https://doi.org/10.1016/j.ejca.2011.01.011

[152] Kasimir-Bauer S, Hoffmann O, Wallwiener D, Kimmig R, Fehm T. Expression of stem cell and epithelial-mesenchymal transition markers in primary breast cancer patients with circulating tumor cells. Breast Cancer Research 2012; 14: 1 9. https://doi.org/10.1186/bcr3099

[153] Lawson DA, Bhakta NR, Kessenbrock K, Prummel KD, Yu Y, Takai K, Zhou A, Eyob $\mathrm{H}$, Balakrishnan S, Wang C-Y Yaswen P, Goga A, Werb Z. Single-cell analysis reveals a stem-cell program in human metastatic breast cancer cells. Nature 2015; 526: 131-135. https://doi.org/10.1038/nature15260

[154] Shekhani MT, Jayanthy AS, Maddodi N, Setaluri V. Cancer stem cells and tumor transdifferentiation: implications for novel therapeutic strategies. American Journal of Stem Cells 2013; 2: 52-61.

[155] Huang Z, Wu T, Liu AY, Ouyang G. Differentiation and transdifferentiation potentials of cancer stem cells. Oncotarget 2015; 6: 39550-39563. https://doi.org/10.18632/oncotarget.6098

[156] Syder AJ, Karam SM, Mills JC, Ippolito JE, Ansari HR, Farook V, Gordon Jl. A transgenic mouse model of metastatic carcinoma involving transdifferentiation of a gastric epithelial lineage progenitor to a neuroendocrine phenotype. Proceedings of the National Academy of Sciences of the United States of America 2004; 101: 44714476. https://doi.org/10.1073/pnas.0307983101

[157] Zelivianski S, Verni M, Moore C, Kondrikov D, Taylor R, Lin M-F. Multipathways for transdifferentiation of human prostate cancer cells into neuroendocrine-like phenotype. Biochimica et Biophysica Acta (BBA) - Molecular Cell Research 2001; 1539: 28-43. https://doi.org/10.1016/S0167-4889(01)00087-8

[158] Choi SY, Gout PW, Collins CC, Wang Y. Epithelial immune cell-like transition (EIT): a proposed transdifferentiation process underlying immune-suppressive activity of epithelial cancers. Differentiation; research in biological diversity 2012; 83: 293-298. https://doi.org/10.1016/j.diff.2012.02.005

[159] Chen HF, Wu KJ. Endothelial Transdifferentiation of Tumor Cells Triggered by the Twist1-Jagged1-KLF4 Axis: Relationship between Cancer Stemness and Angiogenesis. Stem cells international 2016; 2016: 6439864.

[160] Cerasuolo M, Paris D, lannotti FA, Melck D, Verde R, Mazzarella E, Motta A, Ligresti A. Neuroendocrine Transdifferentiation in Human Prostate Cancer Cells: An Integrated Approach. Cancer research 2015 https://doi.org/10.1158/0008-5472.CAN-14-3830

[161] Ha S-A, Kim HK, Yoo J, Kim S, Shin SM, Lee YS, Hur SY, Kim YW, Kim TE, Chung YJ, Jeun SS, Kim DW, Park YG, Kim J, Shin SY, Lee YH, Kim JW. Transdifferentiationinducing HCCR-1 oncogene. BMC Cell Biology 2010; 11: 49. https://doi.org/10.1186/1471-2121-11-49

[162] Marcu M, Radu E, Sajin M. Neuroendocrine transdifferentiation of prostate carcinoma cells and its prognostic significance. Romanian journal of morphology and embryology $=$ Revue roumaine de morphologie et embryologie 2010; 51: 7-12.

[163] Xu B, O'Donnell M, O'Donnell J, Yu J, Zhang Y, Sartor MA, Koenig RJ. Adipogenic differentiation of thyroid cancer cells 
through the Pax8-PPARgamma fusion protein is regulated by thyroid transcription factor 1 (TTF-1). Journal of Biological Chemistry 2016

[164] Fehrenbach S, Novak D, Bernhardt M, Larribere L, Boukamp $\mathrm{P}$, Umansky V, Utikal J. Loss of tumorigenic potential upon transdifferentiation from keratinocytic into melanocytic lineage. Scientific reports 2016; 6

[165] Gattenlöhner S, Brocker E-B, Muller-Hermelink H-K. Malignant Melanoma with Metastatic Rhabdomyosarcomatoid Transdifferentiation. New England Journal of Medicine 2008; 358: 649-650. https://doi.org/10.1056/NEJMc0707079

[166] Cichon L, Gaede J, Sporn T, Rehder C, Lagoo AS. The Transdifferentiation of Mediastinal Germ Cell Tumor into a Myeloid Neoplasm in the Bone Marrow-Report of a Case and Short Review of a Diagnostic Pitfall. 2013 2013; 2

[167] Mori M, Matsushita A, Takiuchi $Y$, Arima H, Nagano S, Shimoji S, Kimura T, Inoue D, Tabata S, Yanagita S, Nagai $\mathrm{K}$, Imai Y, Takahashi T. Histiocytic sarcoma and underlying chronic myelomonocytic leukemia: a proposal for the developmental classification of histiocytic sarcoma. International Journal of Hematology 2010; 92: 168-173. https://doi.org/10.1007/s12185-010-0603-Z

[168] Han X, Li F, Fang Z, Gao Y, Li F, Fang R, Yao S, Sun Y, Li L, Zhang W, Ma H, Xiao Q, Ge G, Fang J, Wang H, Zhang L, Wong KK, Chen $\mathrm{H}$, Hou $\mathrm{Y}$, Ji H. Transdifferentiation of lung adenocarcinoma in mice with Lkb1 deficiency to squamous cell carcinoma. Nature communications 2014; 5: 3261. https://doi.org/10.1038/ncomms4261

[169] Scully S, Francescone R, Faibish M, Bentley B, Taylor SL, Oh D, Schapiro R, Moral L, Yan W, Shao R. Transdifferentiation of Glioblastoma Stem-Like Cells into Mural Cells Drives Vasculogenic Mimicry in Glioblastomas. The Journal of Neuroscience 2012; 32: 12950-12960. https://doi.org/10.1523/JNEUROSCI.2017-12.2012

[170] Ul-Mulk J, Rasmussen H, Breiting L, Siim E. A case of collision tumor or transdifferentiation between malignant melanoma and leiomyosarcoma. Indian Journal of Pathology and Microbiology 2012; 55: 538-539. https://doi.org/10.4103/0377-4929.107806

[171] Terry S, Beltran H. The Many Faces of Neuroendocrine Differentiation in Prostate Cancer Progression. Frontiers in Oncology 2014; 4. https://doi.org/10.3389/fonc.2014.00060

[172] Polyak K, Weinberg RA. Transitions between epithelial and mesenchymal states: acquisition of malignant and stem cell traits. Nature reviews Cancer 2009; 9: 265-273. https://doi.org/10.1038/nrc2620
[173] Hayakawa Y, Sethi N, Sepulveda AR, Bass AJ, Wang TC. Oesophageal adenocarcinoma and gastric cancer: should we mind the gap? Nature reviews Cancer 2016; 16: 305-318. https://doi.org/10.1038/nrc.2016.24

[174] Gao Y, Zhang W, Han X, Li F, Wang X, Wang R, Fang Z, Tong X, Yao S, Li F, Feng Y, Sun Y, Hou Y, Yang Z, Guan K, Chen $H$, Zhang $L$, Ji $H$. YAP inhibits squamous transdifferentiation of Lkb1-deficient lung adenocarcinoma through ZEB2-dependent DNp63 repression. Nature communications 2014; 5 : 4629. https://doi.org/10.1038/ncomms5629

[175] Kong B, Michalski CW, Hong X, Valkovskaya N, Rieder S, Abiatari I, Streit S, Erkan M, Esposito I, Friess H, Kleeff J. AZGP1 is a tumor suppressor in pancreatic cancer inducing mesenchymal-to-epithelial transdifferentiation by inhibiting TGF-beta-mediated ERK signaling. Oncogene 2010; 29: 5146-5158.

https://doi.org/10.1038/onc.2010.258

[176] Stoecker MM, Wang E. Histiocytic/dendritic cell transformation of B-cell neoplasms: pathologic evidence of lineage conversion in differentiated hematolymphoid malignancies. Arch Pathol Lab Med 2013; 137: 865-870. https://doi.org/10.5858/arpa.2012-0104-RS

[177] Pilarski LM, Pilarski PM, Belch AR. Multiple myeloma may include microvessel endothelial cells of malignant origin. Leuk Lymphoma 2010; 51: 592-597. https://doi.org/10.3109/10428191003661860

[178] Ratei R, Hummel M, Anagnostopoulos I, Jahne D, Arnold R, Dorken B, Mathas S, Benter T, Dudeck O, Ludwig WD, Stein $\mathrm{H}$. Common clonal origin of an acute B-lymphoblastic leukemia and a Langerhans' cell sarcoma: evidence for hematopoietic plasticity. Haematologica 2010; 95: 14611466.

https://doi.org/10.3324/haematol.2009.021212

[179] Abdul Aziz M, Sullivan F, Kerin MJ, Callagy G. Malignant Phyllodes Tumour with Liposarcomatous Differentiation, Invasive Tubular Carcinoma, and Ductal and Lobular Carcinoma In Situ: Case Report and Review of the Literature. Pathology Research International 2010; 2010: 501274. https://doi.org/10.4061/2010/501274

[180] Zhang Q, Fan H, Shen J, Hoffman RM, Xing HR. Human Breast Cancer Cell Lines Co-Express Neuronal, Epithelial, and Melanocytic Differentiation Markers In vitro and In vivo. PloS one 2010; 5: e9712. https://doi.org/10.1371/journal.pone.0009712 